\title{
Iscenesat affekt
}

\section{Af Signhild Linderoth Christiansen}

Ev det muligt at fremtrede som gradende kvinde på en scene uden at miste sin bandlekraft og subjektivitet? Kan affektteori og scenekunst samarbejde i et feministisk og normkritisk projekt?

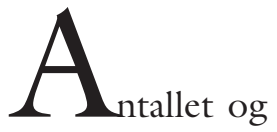

mangfoldigheden af værker, som kan rubriceres performancekunst, er kraftigt øget siden genren etableredes som selvstændigt kunstnerisk udtryk i 1960'erne. Også publikumsinteressen for genren er i dag iøjnefaldende. Det ses blandt andet ved frnomenet performancefestivaler, som eksklusivt koncentrerer sig om genren og dens specificitet. På Caféteatret i København fandt en international performancefestival sted under overskriften Global Emotional Dialogue den 14.-17. maj 2012. Festivalen var et samarbejde med Statens Teaterskoles efteruddannelse, og i forbindelse med festivalen arrangeredes et symposium med danske og udenlandske forelæsere. Temaet var følelser og interesse for, hvordan følelser indgår i det scenekunstneriske møde mellem værk og publikum, herunder hvordan følelser kan have effekt i en global dialog:

[... an international symposium about emotions on display in the dialogue between au- 
dience and stage - you and me - and what effect the emotions have on our communication with others in a global perspective. The symposium aims at exploring the possibilities of putting emotions on stage (Caféteatret 2012).

\section{Arrangementet Global Emotional Dialogue} peger dels på den øgede interesse for performancekunst. Og dels peger det på, at følelser og affekt i samtidskunsten, ligesom inden for en bred vifte af akademiske områder, har opnået status som selvstændigt undersøgelsesområde. Temaets selvstændighed indenfor kunsten repræsenteres i denne artikel ved performanceværket Cry $\mathrm{Me}$ a River (2010) af Anna Mendelsohns, som fremførtes under festivalen.

I denne artikel introducerer jeg først performancekunsten som genre og herefter temaet gråd og tårer. Dernæst introducerer jeg Sara Ahmeds affektteori fokuseret omkring de punkter, jeg finder relevante i sammenhængen: 1) opfattelsen af følelsesmæssig simultanitet mellem krop og tanke og 2) princippet om følelsesmæssige aftryk/ indtryk samt i forlængelse heraf 3) affekt som noget, der er formgivende. Der er tale om affekt forstået som en konstant social proces, som en performativ størrelse og som noget, der altid gør noget.

Herefter præsenterer jeg performanceværket Cry Me a River, som jeg analyserer og diskutererer i en affektteoretisk ramme med hjælp af Ahmeds affektteoretiske principper. Der er således tale om et relativt smalt møde mellem et specifikt værk og specifikke affektteoretiske erkendelser.

Derefter belyser jeg værket og dets tema lidt bredere $\mathrm{i}$ forhold til performancegenrens muligheder og begrænsninger. Artiklen afsluttes med refleksioner om anvendeligheden af kritisk affektteori inden for en bredere kunstvidenskabelig ramme.

\section{PERFormanCE SOM GENRE}

Allerede fra starten var performancekunsten en praksis som i særlig grad knyttede sig til kunstnerens krop og den personlige erfaring. Med kroppen som udgangspunkt undersøges ofte intersubjektivitet mellem performer og publikum og selve mødet er ofte i fokus både rent fænomenologisk og tematisk (Carlson 2004; Jalving 2011: 30).

For den kvindelige kunstner har performancekunsten fremstået som en mulighed for at tage magten over egen krop og eget virke, og som en mulighed for at kommunikere direkte med publikum/beskuer således også for at bryde en forestilling om kvindekroppen som et passivt motiv. "Et af de mest afgørende kønsstrukturerende principper i kunstens historie har været situationen mellem det maskuline kunstnersubjekt og hans feminine nøgne model", skriver kunsthistoriker Ulla Angkjær Jørgensen og forklarer, at dette princip har haft konsekvenser ikke bare for kvinden som motiv, men også som kunster (Jørgensen 2007: 7). I en kunsthistorie, som systematisk har negligeret kvinders kunstneriske produktioner (Ibid.), kan performancekunsten således ses som en potentiel mulighed for den kvindelige kunstner for at bevæge sig uden for de konventioner og tolkningsmæssige strukturer, som omgiver et materielt kunstobjekt.

I de mest optimistiske udlægninger hævdes det, at performanceværket lever på helt egne præmisser og netop ikke er en ting, som kan købes, og derfor undgår at spille en rolle i den etablerede, repetitionsprægede kultur (Jalving 2011: 34). Dette er dog en optimisme, som har fået løbende kritik. For trods et ofte politisk og feministisk engagement har der været mange tvetydige skildringer af den nøgne kvindekrop i performancekunsten. I mange værker har den (afklædte) kvindelige performer bedst kunnet tolkes som videreførende den feminine krop som skue- og begærsobjekt. Værkerne er naturligvis ikke per automatik uinteressante af den grund, men tendensen kan fortælle noget om, at det dels for performeren og dels for den, der tolker, kan være svært 
at bevæge sig uden for det historisk tunge atelier-forhold, uanset om kunstværket er 'en ting' eller en live-performance (Jalving 2011: 42 f.). Performancekunsten må derfor ikke opfattes som synonym med et Butlersk performance-begreb (Butler 1990). Et performancevork er ikke nødvendigvis normbrydende eller forskydende af grænser, blot fordi det tilhører performancegenren. Den gentagelsesstyrede performativitet, som står i modsætning til performance i en Butlersk optik, er nødvendigvis nærværende, også når det handler om kunst.

Uanset problematikkerne forbundet med at forstå performancegenren som autonom kunstart, og som en mulighed for at lade kvindekroppen fremtræde autonomt, må performancegenren tolkes som en vilje til og et behov for, som kvindelig kunstner, at søge udenom og udfordre den mimesis og de kønsrelaterede begrænsninger, som den kunstneriske spilleplads - og tolkningsrammen omkring den - er fuld af (Rosenberg 2000).

\section{GRÅD OG TÅRER SOM TEMA}

Med hjælp fra Sara Ahmeds terminologi kan man sige, at på samme måde som kropslighed og nøgenhed klistrer til individer af kvindekøn, gør det følelsesrelaterede det også. Og med denne klistren følger en nedvurdering af emnet. Feministiske filosoffer har vist hvordan underordningen af følelser også underordner det feminine og kroppen. Som Ahmed skriver:

Emotions are associated with women, who are represented as "closer" to nature, ruled by appetite, and less able to transcend the body through thought, will and judgement (Ahmed 2004: 3).

Overfor det kvindelige og følelsesmæssige står det mandlige og rationelle eller videnskabelige (Rosenbeck 1996). Og i denne sammenhæng placeres det 'kunstnerisk kva- litative' ofte i modsætning til det kvindelige (Hermele 2007: 28).

I særlig grad må netop gråden som følelsesmæssigt udtryk siges at klistre til det kvindelige: Den kvindelige gråd og tårerne har en tryg plads og lever et repetitionspræget liv i kunsten og populærkulturen. Den grædende kvinde er ofte blevet portrætteret på forskellig kunstnerisk vis, og det er svært at finde den teateropsætning eller sitcom, dramaserie eller Hollywoodfilm, som ikke indeholder en kvindes tårer. Kvinden, som græder, er oftest ikke centrum, men fungerer som dramaturgisk/ dramatisk kneb solidt forankret i objekt-positionen. Der kan være tale om de romantiske tårer, de ulykkelige tårer, de rørstrømske tårer, de hysteriske tårer, de manipulerende tårer - eller som oftest lidt af hver slags inden for samme kulturprodukt. Den grædende kvinde er med andre ord en genkendelig og stigmatiseret figur.

Så hvorfor, som selvbestemmende performer, vælge gråden og de følelser, der relaterer sig her til som tema? Tilbyder scenen og selvbestemmelsen ikke netop en mulighed for at fremtræde som kvindeligt subjekt i en anden position? Hvad sker der, når temaet skildres i en sammenhæng uden for et traditionelt og kønnet atelier-forhold, men inden for performancekunstværkets potentielt subversive ramme? For at nærme mig en forståelse må jeg spørge hvordan, performeren gør det, når hun behandler emnet.

\section{SARA AHMED OG KRITISK AFFEKTTEORI}

Inden for den del af affektteori, hvor Sara Ahmed kan placeres, forenes et socialkonstruktivistisk syn på følelser med en fænomenologisk tilgang til kroppen og det erfarede (Koivunen 2008: 13). Trods en søgen (tilbage) mod det materielle og væk fra den rent sproglige og (de)konstruktivistiske læsning af verden er der således tale om en anti-essentialistisk tilgang: Følelser og affekt er i fokus, men man er ikke ude efter endegyldigt at forklare hvad følelser er, 
men derimod vil man analysere hvad de gør bl.a. ved at problematisere følelsernes naturaliserede forbindelse til bestemte sociale kategorier (f.eks. omsorgsfulde kvinder, aggressive mænd, æresfølende arabere osv.). Desuden ønskes en problematisering af opfattelsen af bestemte affekter, som naturligt sammenhængende med bestemte værdier (f.eks. vrede og depression som negative, tilfredshed og lykke som positive). Det fremhæves og pointeres, at følelser er forankrede i en social omverden, hvor visse objekter eller situationer forventes at have visse følelser med vis værdi til følge (Frederiksen 2012: 5 ).

Kroppen udgør det centrum, hvor indre og ydre mødes og sammenblandes, og det er i kroppen tanker og oplevelser formes. Som Elisabeth Grosz forklarer, bliver kroppen i 90er-feminismen "the very "stuff" of subjectivity", og det kan siges at være videreudviklingen af denne kropsinteresse, som er fremtrædende i den samtidige socialkontruktivistisk-fænomenologiske retning af affektteori (Grosz citeret fra Koivunen 2008: 14). Man betragter ikke følelser som ekspressive, de er ikke noget indre, der munder ud i noget ydre, snarere er følelser og affekter at opfatte som "[...] relationelle, performative og "klistrende" " (Frederiksen 2012: 5).

Pointeringen af kroppen i undersøgelsen af det erfarede, er hos Ahmed bl.a. inspireret af Merleau-Ponty og hans kropsfænomenologi. Her er oplevelse altid forankret i kroppen og det sanselige men ikke utroværdig af den grund: Simpelthen er oplevelse per se noget, som må forklares (Koivunen 2008: 13-14).

\section{SimultaniteT MELLEM FØLELSE, TANKE OG AFFEKT}

Ahmed undersøger, hvordan relationen mellem begreberne tanke, sansefornemmelse og følelse (jf. de engelske termer "thought", "sensation", "emotion") ser ud i filosofihistorien (Ahmed 2004: 5). Hun oplever i fi- losofihistorien en opdeling mellem teorier, der tager udgangspunkt $\mathrm{i}$, at følelse forstås som oplevelsen af kropslig forandring (bl.a. hos Descartes og Hume), eller i at følelse altid er tanke eller vurdering (bl.a. hos Aristoletes) - sagt med andre ord: det førsproglige overfor det sproglige. Ahmed betoner, at der er gjort forsøg på at se følelse som begge dele, men at der oftest sker det, at der lægges mere vægt på den ene del, eller at de to dele præsenteres som to adskilte aspekter ved følelse (Ahmed 2004: 5 ).

Men praktisk lader det sig ikke gøre at isolere den fysiske sanseoplevelse og tankemæssig refleksion fra hinanden - derfor er det misvisende at gøre det i teorien. Derimod er der tale om simultanitet mellem oplevelsesniveauerne. For at sprogligt demonstrere denne pointe lader Ahmed de to begreber afløse og erstatte hinanden i tekst. Dette for at understrege den flydende karakter hos frnomenet affekt (Frederiksen 2012: 8).

Ahmed henter hos Descartes opfattelsen af, at objekter ikke i sig selv er gode eller dårlige, og ikke har kausale egenskaber, men at følelser derimod tager deres form af den kontakt, vi har med objekter.

[...] whether something is beneficial or harmful involves thought and evaluation, at the same time that it is "felt" by the body. [...] Contact involves the subject, as well as histories that come before the subject. If emotions are shaped by contact with objects, rather than being caused by objects, then emotions are not simply "in" the subject or object (Ahmed 2004: 5).

Det er afgørende at affekt er noget, som opstår i kontakten og mødet mellem subjekt og objekt, det være sig et forestillet eller reelt møde. Den er ikke at finde som en naturlig forlængelse af hverken objekt eller subjekt i sig selv, men er noget mere flydende, som kræver et møde for at opstå, og som altid involverer tankemæssig så vel som sanselig aktivitet. 


\section{AFTRYK / INDTRYK}

Hos Hume henter Ahmed begrebet 'impression'. Hume bruge det i en betoning af den kropslige sansefornemmelse, som er adskilt fra tankevirksomhed. Ahmed bruger derimod ordet som en sammenkxdende lænke mellem begreberne tanke, kropslig sansefornemmelse og følelse:

I will use the idea of 'impression' as it allows me to avoid making analytical distinctions between bodily sensations, emotion and thought as if they could be 'experienced' as distinct realms of human 'experience' (Ahmed 2004: 6).

Ved hjælp af begrebet 'impression' søger Ahmed altså at favne, hvad hun ser som den samlede menneskelige følelsesoplevelse. Ahmeds engelske term 'impression' oversætter jeg til aftryk og indtryk, eftersom 'impression' kan referere til begge danske udtryk. At "en person har gjort indtryk" (A person made an impression) handler om en persons følelser, hvorimod "jeg har det indtryk" (I am of the impression) handler om at en person har en opfattelse. Mens "jeg har gjort et aftryk" (I have made an impression) handler om et billedligt aftryk, eller "jeg har efterladt et aftryk på en overflade" (I have left an impression) handler om at sætte et mærke eller aftryk på noget. Ahmed påminder om at "[w]e need to remember the 'press' in an impression" (Ahmed 2004: 6). I en dansk oversættelse betyder det, at vi må notere, at der findes et tryk i begreberne af-/indtryk.

Videre åbner betegnelsen af-/indtryk op for det fokus på overflader, som Ahmed udvikler:

[At bruge ordet "impression"] allows us to associate the expirience of having an emotion with the very affect of one surface upon another, an affect that leaves its mark or trace. So not only do I have an impression of others, but they also leave me with an impression; they impress me and impress upon me (Ahmed 2004: 6).
Overfladen er det sted, hvor individ og omverden mødes. Ved mødet påvirkes de overflader, som berøres - og det er her, følelser optræder, og hvor følelserne gør noget ved overfladerne.

\section{AFFEKTEN SOM FORMGIVENDE}

Ahmed kritiserer derfor en ekspressiv forståelse af følelser, hvor følelserne tilskrives en linexr retning, nemlig indefra og siden ud. I en sådan psykologisk model gøres følelser til noget indvendigt $\mathrm{i}$ individet, til 'mine', til noget man kan finde inde i sig selv. Følelserne kan i denne model derefter udtrykkes, de er altså ekspressive, og kan komme ud som f.eks. latter, tårer eller ved en rysten på hovedet. Derefter er mine følelser blevet dine, og du kan reagere på dem. Med kritikken af følelser som ekspressive, tilslutter Ahmed sig den sociologiske og antropologiske gren, hvor følelser snarere forstås som sociale og kulturelle praktikker. Denne opfattelse af følelser som sociale og kulturelle praktikker finder Ahmed bl.a. i Durkheims sociologiske tekster, og man kan tale om en 'udefra og ind'-model. Her er følelserne noget, der opstår kollektivt og siden arbejder sig ind $\mathrm{i}$ individerne. Man skifter individet ud med masserne - men stadig er følelser noget, massen 'har'. Men Ahmed afgrænser sig også fra denne gren (Ahmed 2004: 9), idet hun oplever, at samme problem er forbundet med begge modeller:

The "inside out" model has become an "outside in" model. Both assume the objectivity of the very distinction between inside and outside, the individual and the social, and the "me" and the "we" (Ahmed 2004: 10).

At der er en allerede eksisterende grænse mellem det ydre og det indre, hvor imellem følelserne opererer, indikerer en problematisk distinktion. Ifølge Ahmed er det netop følelserne, som skaber den effekt hos overflader og grænser, som gør det muligt for 
os overhovedet at afgrænse et indre og et ydre:

So emotions are not simply something 'I' or 'we' have. Rather, it is through emotions, or how we respond to objects and others, that surfaces or boundaries are made: the ' $\mathrm{I}$ ' and 'we' are shaped by, and even take the shape of, contact with others (Ahmed 2004: 10).

Kroppe får deres overflader som en effekt af de ind-/aftryk, andre efterlader. At vi laver distinktioner mellem det psykologiske (private indre) og det sociale (fælles ydre), må derfor betragtes som en effekt af følelserne selv. Afgrænsningerne som muliggør et “og” i “socialt og psykologisk" må derfor forstås som en misvisende konstruktion (Ahmed 2004: 10). De to områder hænger sammen, og grænserne mellem de to bestemmes af affekt og er konstant i bevægelse.

Det kan siges, at følelserne materialiseres ved at forbindes til objekter. Og at denne forbindelse er lig med vores involvering i verden. Hvor grænserne går mellem subjekt og objekt - hvor den ene overflade starter og den anden slutter - er en følelsesmæssig bestemmelse. Affekt er i sin karakter formgivende.

\section{PerformancevÆrket Cry Me}

\section{A RiVER}

Cry Me a River af Anna Mendelssohn ( *1976) havde premiere i maj 2010 og har vundet flere priser. Performancen åbner med billedet af Mendelsohn siddende ved et langt konferencebord. Hun er helt alene, og har flere tomme stole på begge sine sider. Der står mikrofoner på bordet, og det ser professionelt og politisk ud. Og det er det også - på flere niveauer. Emnet for den dramatiserede og opløste forelæsning, denne performance lecture, er klimaforandringerne. Emnet pendler i tekst og fysiske udtryk mellem Mendelssohns personlige fortvivlelse og en gråd, som ikke vil stoppe, til information om klimaets pressede tilstand og de smeltende poler. Isen smelter, og det samme kan siges om Mendelssohn. Ud af Mendelssohns mund strømmer diverse indlæg fra klimadebatten på engelsk og tysk: Vrede aktivistiske stemmer, pædagogiske, optimistiske hjælperåd til et mere klimavenligt liv a la "sluk motoren, når du holder for rødt i bilen”, arrogante, økonomisk- og businessorienterede argumenter for uændret klimapolitik, fortvivlede moderjordudråb og distancerede politiske ræsonnementer. Hver og et af tekstpartierne er indbagt i stærkt følelsesmæssigt engagement fra performeren. Mellem de politiske fragmenter kommer udlægningerne om Mendelssohns personlige fortvivlelse: “[...] at some point I began to cry. And that went on for many months" (Mendelssohn 2010). ${ }^{1}$ Hun fortæller om en forgangen periode $\mathrm{i}$ sit liv. Hun oplevede, at den ydre klimakrise strakte sig ind i den private tankeverden - og det er også det, der sker rent dramaturgisk på scenen i performanceværket. Hun kan ikke bære klimaets håbløshed, og hun kan ikke overskue sin personlige situation. Således forklarer hun parallelt med fortvivlelsen over klimasituationen en frustration over, ikke at have fået børn inden $\sin 30$ - årsalder, stress over hvordan hun skal finde en mand at få børn med og hvordan bliver det så med det liv, hun nu lever og elsker? Hun kan ikke bære, at der ikke er en enkel løsning eller en enkel måde at forholde sig til situationen på, og det gælder både klima- krisen og det personlige: “[...] everything is so much more complicated than you think. There are a million little strings attached to every choice you make" (Mendelssohn 2010).

Mendelssohn er indlevelsesfuld i sine forskellige udsagn fra den politiske debat og om sit privatliv. Hun kalder så intenst på publikums engagement, at jeg først et godt stykke tid inde i værket for alvor indser, at der er tale om en leg med diskurser, og at ordene fra klimadebatten er kopierede citater. Det er først ved et lille, ironisk glimt, 
ved tekststykket med de pædagogiske råd til en klimavenlig hverdag, at jeg kan identificere konceptet.

Syv minutter inde i performancenværket benytter Mendelssohn første gang den tårestift, som står opstillet ved siden af et vandglas på bordet foran hende. Den smører hun under øjnene, og tårerne løber. Til lyden af sentimental musik smører hun gang på gang et nyt lag på. Det hele svømmer over, og i disse tilbagevendende sekvenser går Mendelssohn over til de personlige krisefortællinger. Men tårerne følger med ind i de klimapolitiske tekststykker og illustrerer, at den kontrollerede rationalisme som forventes her, ikke er at finde. Følelserne er yderst nærværende, også når der tales klimapolitik.

Mendelssohns ydre ændrer undervejs karakter. Hun putter lim eller voks på ansigtet og hænder, som hun trevler op, mens hun taler, så det ser ud som om, hun krakelerer. Hun maler brune og sorte plamager i ansigtet. Da hendes performance er ovre, ligner hun noget, der er ved at forgå.

På samme måde som Mendelssohn blotter følelsernes rolle i klimadebatten, resulterer hendes performance også i en blotlæggelse af følelsernes ofte uproblematiserede og relativt statiske tilstedeværelse $\mathrm{i}$ scenekunsten. Mens følelserne i det traditionelle drama lever sit liv under overfladen, motiverer og sporer handlingen, flyder de her langt op over overfladen og skaber oversvømmelse, de bliver centrum og strukturerende for værket. Den føromtalte selvstændighed, som temaet følelser tildeles inden for kunsten, handler derfor også om tematisk selvstændighed $i$ verket. Mendelssohn er det sansende centrum i fortællingen, og det er hendes følelser, som skaber handling, kommunikation og struktur i værket. I Cry $M e$ a River vendes så at sige vrangen ud på værket, så følelserne blottes og bliver værkets ydre, som et dramaturgisk og analytisk greb.

\section{AfFekT I CRY Me A River}

Når det handler om at forbinde scenekunst og affektteori, er er jeg nødt til at forholde mig til, at de følelser, som præsenteres for publikum, helt eller delvis er indstuderede og fastlagte af performeren/instruktøren. I en værkanalyse er det ikke muligt at klarlægge de følelsesmæssige processer, performeren gennemgår under eller inden performancen. Det, jeg kan analysere, er simpelthen det iscenesatte udtryk som præsenteres for publikum, og derfor har jeg kun min egen perception af dette udtryk at gå til. En analyse vil derfor handle om det udtryk jeg oplever, og hvordan jeg oplever, at værkerne kommunikerer med mig. En omstændighed som kan synes indlysende, men som særligt må pointeres, når det handler om at belyse affekt. Lidt firkantet kan det hævdes om et traditionelt skuespil, at det, som publikum ser, er følelser præget af tanke og refleksion, som er blevet iscenesat som affektive udtryk. Skuespilleren lever sig ind i en følelse, forestiller sig den og spiller sine spontane, affektive udtryk, ofte forestilling efter forestilling. De er ikke spontane. Dette er dog en grov forenkling af skuespilkunsten, men som udgangspunkt er det $\mathrm{i}$ denne indstuderede form, at affekt lader sig studere udefra i scenekunst.

Situationen bliver imidlertid mere kompleks i performancekunsten. Kunstformen har en genremæssig tradition for, at det umiddelbare, intersubjektive og undersøgende bevidst prioriteres (Jalving 2011: 32), og det påvirker også det følelsesmæssige. Og det skaber en åbning mod Ahmeds affektteori, hvor affekt netop simultant både er noget 'indstuderet' (tankepræget, sprogligt) og 'spontant' (sanseligt, førsprogligt).

\section{SimUlTANITET MELLEM FØLELSE, TANKE OG AFFEKT I VÆRKET}

Baggrunden for Mendelssohns værk er en oplevelse i og af det individuelle følelsesliv. Derfor er der tale om to overordnede ni- 
veauer i det sceniske: Som baggrund ligger den oprindelige oplevelse af en følelsesmæssig situation, som performeren gennemgående refererer til. Det er ikke muligt at vide, om oplevelsen virkelig har fundet sted, men værket præsenteres som selvbiografisk, og jeg vil behandle det som sådan. Mod denne baggrund udspiller den dramatiserede performance sig, den foregår i nuet, hvor den oprindelige oplevelse genfortælles og delvist re-enactes. Baggrunden for Cry Me a River skal således findes i Mendelssohns oplevelse af håbløshed og fortvivlelse over klimaets tilstand. Kroppen er centrum og bliver i værket "the very 'stuff' of subjectivity" (Koivunen 2010: 14). Det er Mendelssohns krop, som er udgangspunkt og indgangspunkt for mødet mellem subjektiviteten og den ydre verden, mellem sansefornemmelser og tanker. Og det er kroppen, der forbinder baggrundshistorie med live-situationen. Hun beskriver tårerne og grådanfaldene, som ikke vil stoppe. Genfortællingen af baggrundsoplevelsen gøres på en måde, hvor tanke, kropslig fornemmelse og følelse smelter sammen til en helhed på scenen. Det er et scenisk valg, en måde at formidle sin historie på, hvor det følelsesmæssige udtrykkes gennem alle kanaler. Kroppen udtrykker affekt med sin ageren og gråd, ordene forklarer selve følelsen og tankerne om følelsen - og det gøres simultant mellem kanalerne: Den fortvivlelse og det forfald Mendelssohn iscenesætter, strømmer gennem hendes samlede udtryk. Det er et følelsesmæssigt helhedsudtryk på linje med Ahmeds definition af affekt, hvor affekt, følelse og tanke ikke kan separeres. Det lader sig ikke gøre at formidle oplevelsen som alene sanselig og kropslig, følelsesmæssig eller tankemæssig. Hvorfra følelsen opleves og formidles at udspringe fra, varierer. Dette understreges bl.a. med tårestiften: Den sætter noget i gang rent kropsfænomenologisk og er samtidig forbundet til, og understreger kropsligt, en indre stemning, som Mendelssohn søger at formidle.

\section{AFTRYK / INDTRYK I VÆRKET}

Når vi vender tilbage til princippet om af-/indtryk, må det fremhæves, at Mendelssohns baggrundsoplevelse netop fremlægges som at den ydede et tryk. Den gjorde indtryk, satte aftryk på hende. Et tryk som manifesterede sig som sansefornemmelse, følelse og som aktivering af tankemæssig refleksion. Det er dette tryk, hun iscenesætter og delvist re-enacter i sit værk. Hun illustrerer det bl.a. ved at 'male affekten’ på sin krop med sminke. Følelserne er på den måde ikke løsrevet fra Mendelssohns omverden og dens objekter, men i høj grad i dialog hermed.

Det er i relationen mellem Mendelssohn og omverdenen affekt udspiller sig. Affekt sætter relationen mellem Mendelssohn og den ydre verden i bevægelse, og det er en smertefuld oplevelse. Mendelssohns affekt gør noget ved overfladerne, hvilket jeg vil uddybe i næste afsnit.

Også når Mendelssohn imiterer de mange stemmer fra klimadebatten, illustrerer hun hvordan, noget ydre gør indtryk på hende, noget udefra sætter aftryk i hende, som siden også bliver til (sceniske) udtryk. Hun imiterer et væld af diskurser overbevisende, og på den måde pointerer hun dels det teatralske element hos diskurserne, og dels problematiserer hun et autenticitetsbegreb. Hvem mener hvad? En samlet debat personificeres af performeren og peger på den flydende karakter hos grænsen mellem indre og ydre, det individuelle og sociale, jeg'et og vi'et (Ahmed 2004: 10).

\section{FORMGIVENDE AFFEKT I VÆRKET}

Jeg oplever, at værket netop handler om den flydende karakter mellem subjekt og omverdenen. Med opfattelsen af affekt som formgivende kan man sige, at affekt ikke bare bevæger sig mellem, men også former Mendelssohns relation til omverdenen: Følelsen skaber grænsen mellem hende som subjekt og den øvrige verden. Det er følelsen af fortvivlelse, som skaber en afgrund 
mellem hende og omverdenen. Omverdenen formes for Mendelssohn som noget uendeligt kompliceret, skræmmende og truende. Med andre ord: Affekt, som det fremlægges i den oplevelse, som ligger bag performanceværket, er således alt andet end et statisk eller iboende fænomen. Det er noget, som udspiller sig i mødet mellem Mendelssohn og omverdenen, og det er noget, som former Mendelssohn forhold til den verden, hun lever i. Affekt kan ikke bestemmes som noget, der kommer indefra og bevæger sig ud - eller udefra og ind. Det illustrerer Mendelssohn med værkets fragmentariske form og indhold.

Grænsen mellem værk/performer og publikum er derfor også i bevægelse under selve live-situationen, hvilket belyses herunder.

\section{FORMGIVNING AF LIVE-MØDET MELLEM VÆRK OG PUBLIKUM}

Hvis vi vender tilbage til spørgsmålet om, bvordan Mendelssohn skildrer affekt, er distance et vigtigt greb. For hun spiller jo sin affekt - og ikke bare det, hun udstiller, at hun spiller den. Det affektive udtryk, nemlig tårerne, som hun leverer i live-situationen er jo fremkaldt af en tårestift, og det fysiske forfald hun viser, er fremkaldt af sminke. Det er fake. Fordi brugen af virkemidlerne, tårestift og sminke, er iscenesat og koreograferet i værket, ved jeg, at affekten ikke er ' $x g t e$ '. Hun bruger virkemidlerne med største alvor, og som publikum ser jeg, at performeren ikke ønsker, at jeg skal tro at affekten er xgte. Hun er åben og xrlig med, at der er tale om teatralske virkemidler. Det bemærkelsesværdige er, at jeg alligevel bliver berørt af hendes tårer og fysiske forfald. Første gang Mendelssohn benytter tårestiften til den sentimentale musik, fremkalder det latter. Men det er en dedikeret latter, som ikke hindrer, at hun efterfølgende tages højst alvorligt. Når tårestiften er stillet tilbage på sin plads, og tårerne triller, ligner hun en 'naturligt' græ- dende person, og jeg tolker hende som det. Det er lidt besynderligt; processen med tårestiften bliver som en ufuldstændig eller afbrudt Verfremdungseffekt (Brecht 1982).

Også for mødet med publikum er performerens krop centrum, og den kommunikerer med mig. Selve den fysiske åbenbarelse af gråd kalder på min medfølelse og mit engagement. At se hende græde virker så bekendt, som om jeg har set det før. Som kunsthistoriker Camilla Jalving beskriver, berøres vi ofte af kunsten, der hvor vi er vant til at blive det, simpelthen fordi vi er blevet det før (Jalving 2011: 182). At se en person græde af smerte, særligt en kvinde, er sådan et sted, hvor vi dramaturgisk er vant til at blive, eller forventes at blive, berørt. Det ligger i linje med Ahmeds beskrivelse af, at det som har affektiv effekt på os, er det, som giver os "a dwelling place"; et velbekendt sted at falde til ro og føle os hjemme (Ahmed 2004: 11). Det, som bevæger os, er også det, som holder os 'på plads' og fortæller os, hvor vi hører til.

Men det er dog ikke muligt at hvile her særligt længe. At tårerne er falske umuliggør at grædescenerne ureflekteret kan fungere som 'hvilested'. Snarere pendler jeg mellem min velkendte sympati med scenens grædende kvinde på den ene side og på den anden side en tvungen og nydelsesfuld afstandtagen, fordi hun også er en slags parodi på selvsamme figur. Jeg sidder i en kompleks situation. Det komplekse består bl.a. i at Mendelssohn agerer meget naturalistisk. Hendes spil bærer ikke præg af parodi, men af kraftfuld indlevelse. Jeg er vant til at ville leve mig ind $\mathrm{i}$ det på scenen fortalte og pendler mellem afstand og indlevelse: Er vi allierede eller laver du grin med mig? Skal jeg åbne mig eller lukke mig?

Det vellykkede resultat af at fremprovokere denne pendlen mellem distance og sympati hos mig som publikum bliver en blotlæggelse af det manipulerende ved følelser og ikke mindst ved tårer. Jeg sidder der og oplever, at jeg køber dem følelsesmæssigt, jeg berøres af dem, samtidig med 
at jeg ser, at de er falske. Dette dilemma er overordnet også repræsenteret af det komplekse ved at performerens indlevelse i værkets tekst, som jo er kopierede citater. Den følelsesmæssige forankring, de har hos hende, er fake. Det bliver en både kropslig og tankevækkende oplevelse af, at følelser er manipulerende, og at vores måde at udøve følelsesmæssigt engagement er rutinemæssig og kontekstafhængig. Det blotlægges, at det er et tolkningsspørgsmål, i hvilken grad jeg tillader mig at blive påvirket følelsesmæssigt: Jeg åbner eller lukker mig for visse følelsesmæssige engagementer og visse følelser afhængigt af, hvor de opstår, og i hvilken grad jeg tolker dem som passende eller ægte: I en politisk tekst, i en videnskabelig rapport, i en roman, i en vens oplevelse eller på en scene.

I relationen mellem værk og publikum er det altså på samme måde, som det er affekt, der dikterer grænsen mellem Mendelssohn og omverdenen, min affekt, som afgør, hvor grænsen går mellem mig som publikum og hendes performance. Mit forhold til Mendelssohns performance punkteres hele tiden af hendes parodi kontra indlevelse. Skiftevis fjernes jeg fra hende og føres nærmere hende, og jeg oplever, at det netop er min affekt, som styrer denne pendlen. Affekten fremtræder derfor også i denne relation som formgivende: Om jeg er åben eller lukket, hvor grænsen går mellem mig og Mendelssohns værk, er styret af min følelsesmæssige status.

Men hvordan påvirkes Mendelssohn i live-processen af mødet med mig, med publikum? Hvis der i performancegenren, ud over de tilrettelagde følelsesudtryk, er plads til noget mere følelsesmæssigt spontant (Jalving 2011: 30), hvor skal vi så finde det i værket? Det er som sagt ikke muligt at vide, hvordan performerens affektive processer arter sig for hende på scenen. Men på baggrund af en publikumssamtale med performeren efter fremførelsen af værket, ved jeg, at visse momenter er åbne, på den måde at Mendelssohn agerer ud fra den respons, hun får af sit publikum. ${ }^{2}$ I samtalen forklarede hun, at det sted, hvor hun den første gang i performancen bruger tårestiften, oftest plejer at lade tårerne komme 'af sig selv', hvilket de faktisk gør. Men ved den aktuelle performance i maj 2012 syntes hun, at kontakten med publikum var for svag. Det havde hun prøvet før, og når det sker, bruger hun tårestiften for at få bedre kontakt: Hun har erfaret, at det er en effekt, som vækker affekt. Brugen af tårestiften engagerer publikum. Muligheden for at gøre dette valg, tolker jeg som en åbenhed fra Mendelssohn overfor publikum. Hun er nærværende, og lige så vel som hun sætter aftryk i os, gør vi indtryk på hende. Indtryk hun svarer på ved f. eks. at bruge tårestiften eller ikke at gøre det. Eksemplet med tårestiften gør det muligt at tro, at Mendelssohn også i værkets øvrige partier svarer på publikum, men med mere subtile midler, som ikke er lige så tydelige som en tårestift, og som derfor ikke kan udkrystalliseres i en værkanalyse. Men jeg ser, at hun er nærværende i sin kontakt: Jeg ser, at hun ser os i øjnene under hele performancen, at hun taler direkte med sit publikum. Jeg tolker det som, at Mendelssohn i live-performancen påvirkes af det affektive tryk, publikum yder på hende.

Det vil i forlængelse sige, at skildringen af den oprindelige oplevelse påvirkes af nuet og de tryk Mendelssohn udsættes for. Og det peger igen på affekt som formgivende af grænsen mellem ydre og indre: Mendelssohns affektive tilstand påvirkes af publikum i nuet under live-performancen, og denne affektive tilstand påvirker, hvor grænsen går mellem ydre og indre $i$ hendes fortælling. Sagt på en anden måde: Fra performerens perspektiv går grænsen mellem ydre og indre kun der, hvor hun foler, at den går, og denne følelse er til forhandling med publikum i nuet, og forankres i hendes udtryk og ageren, som præger den historie, hun fortæller om et møde mellem subjektivitet og den ydre verden. 


\section{ET SUBVERSIVT POTENTIALE?}

Så hvordan gør Mendelssohn, når hun iscenesætter affekt? Forestillingen pendler mellem mange forskellige lag og bindes sammen af tårerne, som løber som en flod gennem værket. Det er Mendelssohns affekt - i nuet og som hun husker den oprindelige oplevelse - som formgiver værkets fortælling. Hvordan jeg forholder mig til værket, er styret af min punkterede, affektive respons. Man kunne kalde hendes skildring af følelser kropsligt frenomenologisk - i lighed med Ahmeds - men scenisk: Hun viser, hvad affekt gør ved hendes krop, og hun viser tårernes materialitet ved hjælp af tårestiften. Kroppen fungerer som det sted, hvor indre og ydre sammensmelter til uadskillelighed. Også en socialkonstruktivistisk tilgang kan findes i værket - igen i lighed med Ahmed. Ved at opløse en distinktion mellem essens og konstruktion kasseres ambitionen om at sige, hvad følelser er. Derimod skildres det scenisk, hvad følelserne gør ved både sind og krop, og relationen mellem subjekt og omverden relativeres. Det kropslige er i fokus, men hvor grænserne for denne krop går, er styret af relationelle, sociale processer.

Er Cry Me a River alligevel endnu et kulturprodukt, som naturaliserer den negativt valoriserede forbindelse mellem kvinder og følelser, mellem kvinder og gråd? Kunstog performancehistorikeren Amelia Jones pointerer, at evnen til at rykke ved strukturer, som tilskrives performancekunst, er et potentiale og ikke en nødvendighed. Det ville således være svært at forklare, hvorfor vi endnu, efter alle performanceværkerne siden 1960erne, stadig lever under de strukturer, som der allerede da gjordes oprør mod. Som analytiker af performancekunst er det desuden nødvendigt at indse sin egen deltagelse i herskende strukturer:

I would be catching myself in a fundamental hermeneutic dilemma, since I would be defining works that supposedly will not allow definitiv interpretation (and suggesting that I am somehow 'outside of' the structures and assumptions of conventional interpretive models) (Jones 1998: 5).

Vi er ikke i stand til at tolke et værk udenfor de herskende strukturer, som både værket og jeg, som oplever og analyserer det, eksisterer i. Det vil sige, at den betydning, vi har mulighed for at tilskrive et værk, også er begrænset. Og visse følelser og kønnede konnotationer klistrer til visse objekter med stor kraft, hvorfor en separation kan forekomme umulig.

Trods disse begrænsede oplevelsesmuligheder, mener jeg, at det lykkes værket at omgå sit tema i et nyt lys. Den refleksion, værket vækker, kan siges, at være en konsekvens af den eksplicitte rolle følelserne tildeles og af performerens position som kvindeligt og grædende subjekt. De følelser og udtryk, det handler om på scenen, er traditionelt negativt valoriserede. Tvivl, håbløshed og frustration kan ikke karakteriseres som velkomne følelser. Mendelssohn taler i sit værk om, at hun i sin krise måtte minde sig selv om, at: "[...] There is such thing as uncertainty. That's a good thing!" (Mendelsohn 2010). Det er et udsagn, som søger at opvurdere det nedvurderede. Værket viser en mulighed for aktivt at gå ind $\mathrm{i}$ den dialog, som følelserne allerede fører med omverdenen og bruge følelserne som en mulig vej til handlekraft. Det gør værket ved at fremhæve tvivl og stærke følelser som noget 'godt', og frem for alt ved at forvandle de 'negative' følelsestilstande, som er baggrunden for værket, til handlekraft i form af performancekunst. Smerten de- patologiseres, sådan som f.eks. Cvetkovich taler for: "Målet er at de-patologisere negative affekter, så de kan ses som mulige ressourcer for politisk handling, snarere end det modsatte" (Cvetkovich 2007: 460, min oversættelse). I værket gives desuden konkrete bud på en anden mulig verden. Mendelssohn taler om usikkerhed som noget fint, en egenskab som er god - og hun taler om, at det hun ønsker for fremtiden, er: 
"[...] some kind of social, playful cooperative, where, you know [...] relatively low consumption, non-consumerism [...] where you can just run around naked, wear some feathers and not being picked up for it. That's not too big a dream."

Den følende og grædende kvinde tager plads på scenen som subjekt. Det kan i bedste fald, være med til at udvide og forskyde kategorierne Kvinde, Gråd og Subjekt.

\section{AFFEKTTEORI I KUNSTVIDENSKABEN}

At føre affektteori ind i kunstvidenskabelige sammenhænge ligger ifølge min opfattelse i linje med aktuelle bud på nye metodiske og teoretiske måder at møde (samtids)kunsten på, som bl.a. Jalving (2011) lægger frem. Den subjektive sansning og interessen for, hvordan subjektet indgår i mødet med kunsten, er i fokus.

Ahmed forener en socialkontruktivistisk med en fænomenologisk tilgang på overbevisende måde, og jeg ser i dette spændingsfelt givende åbninger både mod det specifikt performanceteoretiske felt og det samtidskunstneriske. En søgen tilbage til kroppen og opgøret med en lingvistisk forståelse af subjektet er en god hjælp, når jeg nærmer mig en feministisk analyse af en performance.

Følelser får en yderst performativ karakter hos Ahmed, hvilket gør hendes grundforståelse af, hvad følelser er, relevant, når det handler om performancekunst. Vi gør noget, når vi møder kunsten, og i denne gøren spiller følelserne en central rolle. At det aktuelle værk eksplicit og tematisk handler om følelser, gør blot denne rolle end mere central.

Ligeledes appellerer Ahmeds fokus på overflader og møder til et samspil med æstetisk analyse. I en værkanalyse indebærer det en åbning mod værket eller den handlende performer som kropsligt subjekt og som nogen, jeg som publikum indgår i en følelsesmæssig og sanselig relation med, når jeg oplever værket. Med hjælp fra de affektteoretiske termer bliver det muligt at sætte nye ord på relationen mellem værk og publikum

Anu Koivunen præsenterer Ahmed dels under den socialkonstruktivistisk-fænomenologiske retning inden for affektteorien. Men Koivunen placerer også Ahmed under den retning, hvor forskeren udfører den magtkritiske og politiske gerning, det er at analysere "the psychic life of power", en retning som beskrives under overskriften "The cultures and politics of emotions: Affects, norms and power" (Koivunen 2010: 20 ). Ahmed er tydeligt inspireret af postkolonialisme og queerteori og følelser ses som noget, der skaber magtstrukturer og in- og eksklusioner i samfundet. Hendes agenda er samfundskritisk og politisk på ganske konkret vis. Det er således ikke selvskrevet, at Ahmeds teori egner sig til en mere kunstteoretisk performanceanalyse. På den anden side er det netop dette uselvskrevne, som gør mødet områderne imellem frugtbart. Den politiske agenda hos Ahmed og normkritisk affektteori muliggør netop, at en performanceanalyse kan gøres til mere end æstetisk værkanalyse. Den muliggør måder at se det på scenen fortalte i bredere og tværfaglige perspektiver, det åbner op for elementer, som så let går tabt $\mathrm{i}$ æstetisk analyse. Og den anden vej rundt: En så kropsligt orienteret affektteori fortjener at få kroppe at virke med, og det kan performancekunsten bistå med.

Affektteori kan med andre ord på en distinkt måde være en hjælp til at forklare og reflektere over vores kunstneriske oplevelser. For oplevelse er med Merleau-Pontys ord per se noget, som må forklares (Koivunen 2008: 13-14). Det er både det behandlede værk og performancekunsten som genre et talende eksempel på. 


\section{NOTER}

1. Denne og følgende citerede replikker kan også findes i traileren for performancen, se Mendelsohns (2011).

2. Artist Talk efter fremførsel af værket den 15 . maj 2012. Se Global Emotional Dialogue: http://www.teaterskolen-efteruddannelsen.dk/sider.php?id=354

\section{LITTERATUR}

- Ahmed, Sara (2004): The Cultural Politics of Emotion. Edinburgh University Press, Edinburgh. - Ahmed, Sara (2010): The Promise of Happiness. Duke University Press, Durham.

- Ahmed, Sara (2006): Queer Phenomenology: Orientations, Objects, Others. Duke University Press, Durham.

- Ahmed, Sara (2011): Vithetens Hegemoni. Tankekraft, Hägersten.

- Brecht, Bertolt (1982): Om tidens teater (red.): Siegfried Unseld. Gyldendal, Haslev.

- Butler, Judith (1990): Gender Trouble: Feminism and the Subversion of Identity. Routledge, New

York.

- Caféteatret (2012): Program for Global Emotion Dialogue - International Performace Festival Symposium. Lokaliseret den 20/42013 på

http://www.cafeteatret.dk/2011-12/SymposiumGlobal\%20Emotional\%20Dialogue.pdf - Carlson, Marvin Albert (2004): Performance: A Critical Introduction. Routledge, New York. - Frederiksen, Maja Bissenbakker (2012): Styr dine følelser!, i: Varia 2012 /9: I affekt. Skam, frygt og jubel som analysestrategi. Center for kønsforskning, Københavns Universitet.

- Hermele, Vanja \& Stone, Nina (2007): I Vüntan på vadå? Teaterförbundet guide till jämställdhet.

Premiss \& Teaterförbundet, Stockholm. - Jalving, Camilla (2011): Vark som handling: Performativitet, kunst og metode. Museum Tusculanums Forlag, København.

- Jones; Amelia (1998): Body Art / Performing the Subject. The University of Minnesota Press, Minneapolis.

· Jørgensen, Ulla Angkjær (2007): Kropslig kunst. Astetik, køn og kunstanalyse. Museum Tusculanums Forlag, København.
- Koivunen, Anu (2010): An affective turn?, i: Liljeström, Marianne og Paasonen, Susanna (eds.): Working with Affect in Feminist Readings. Disturbing differences. Routledge, London.

- Mendelsohns, Anna (2010): Cry Me a River. Performance, lokaliseret den 20/4 2013 på http://annamendelssohn.net/

- Mendelsohns, Anna (2011): Cry Me a River. Trailer, lokaliseret den 20/4 2013 på http://www.youtube.com/watch?v=fShMjP8ae2o - Rosebeck, Bente (1996): Kroppens politik. Om køn, kultur og videnskab. Museum Tusculanums Forlag, København.

- Rosenberg, Tiina (2000): Byxbegär. Anamma, Göteborg.

\section{SUMMARY}

The performance Cry Me a River (2010) by Anna Mendelssobn is a solo about inner and outer climate catastrophes. The act of crying is central, and emotions are treated explicitly during the performance. When affect is presented this way, it affects the whole dramaturgy as well as the relationship between the audience and the work of art. In the article key terms of the affect theory by Sara Abmed are applied in an analysis and a discussion of the performance. Affect appears as a cultural and relational phenomenon, and "thought", "sensation" and "emotion" always exist simultaneously. The article suggests that critical affect theory offers theoretical tools for communicating about emotions in art. It also suggests and that affect theory is useful in the development of feminist theories concerning the encounter between audience/scientist and art, as it describes how emotions always emerge midway between subject and object, and always are related to structures of power.

Signhild Linderoth Christiansen

Cand.mag. i Moderne kultur 